\title{
ANALISIS FAKTOR PENYEBAB RENDAHNYA MINAT BELAJAR SISWA TERHADAP MATA PELAJARAN MATEMATIKA DI MTs ULUL ALBAB
}

\author{
Cep Bambang Firdaus \\ IKIP Siliwangi, Jl. Terusan Jendral Sudirman, Cimahi Tengah, Kota Cimahi, Jawa Barat \\ bfirdaus041@gmail.com
}

\begin{abstract}
This study aims to analyze the factors that cause low interest in students' learning in mathematics at MTs Ulul Albab. The method used in the research is the survey method. The research technique was carried out by distributing questionnaires which were then analyzed descriptively. Questionnaire consists of 24 items related to 1) feelings (11 questions), 2) attention in learning (5 questions), and 3 ) interest in the material and the teacher (8 questions), with 2 alternative answers to the questionnaire namely "Yes" and "No". The population of this study were all MTUL Ulul Albab students, while the sample was 60 students from various grade levels, consisting of 30 VII grade students, 30 VIII grade students, and 30 IX grade students. The results showed that the causes of low student learning interest in mathematics subjects were influenced $(41.53 \%)$ at a moderate level enough to determine the low interest in learning mathematics, this condition is expected to increase again for the future
\end{abstract}

Keywords: Interest in Learning, Mathematics Learning

\begin{abstract}
Abstrak
Penelitian ini bertujuan untuk menganalisis faktor penyebab rendahnya minat belajar siswa terhadap mata pelajaran matematika di MTs Ulul Albab. metode yang digunakan dalam penelitian adalah metode survei. Teknik penelitian ini dilakukan dengan melakukan penyebaran angket yang selanjutnya dianalisis secara deskriptif. Angket terdiri dari 24 butir pertanyaan yang berhubungan dengan 1) perasaan (11 butir pertanyaan), 2) perhatian dalam belajar ( 5 butir pertanyaan), dan 3) ketertarikan pada materi dan guru (8 butir pertanyaan), dengan 2 alternatif jawaban pada angket yaitu "Ya" dan "Tidak". Populasi dari penelitian ini adalah seluruh siswa MTs Ulul Albab, sedangkan sampelnya yaitu 60 siswa dari berbagai tingkatan kelas, yang terdiri dari 30 siswa kelas VII, 30 siswa kelas VIII, dan 30 siswa kelas IX. Hasil penelitian menunjukan bahwa faktor penyebab rendahnya minat belajar siswa pada mata pelajaran matematika dipengaruhi $(41.53 \%)$ pada tingkatan sedang cukup menentukan rendahnya minat belajar matematika, keadaan ini diharapkan adanya peningkatan lagi pada masa yang akan datang.
\end{abstract}

Kata Kunci: Minat Belajar, Pembelajaran Matematika

Pendidikan adalah proses interaksi antara pendidik dan peserta didik baik secara formal, nonformal maupun informal (Rasnawati, et. al., 2019). Salah satu mata pelajaran yang penting dalam dunia pendidikan adalah matematika. Pembelajaran matematika memiliki peran yang penting dalam proses pendidikan untuk berbagai jenjang (Akbar et. al, 2018:144, ) dan dapat memanfaatkan kedalam kehidupan sehari-hari (Bernard, Akbar, Ansori, \& Filiestianto, 2019; Chotimah et. al, 2018:68; Rahmawati et. al, 2018:344; Sugandi \& Akbar, 2019; Isnaeni, et. al., 2018; Wiliawanto, et. al., 2019).

Matematika adalah mata pelajaran berhitung, termuat dalam mata pelajaran lain yang memiliki perhitungan juga, seperti fisika, kimia dan ilmu eksak lainnya serta membantu memecahkan masalah dalam segala bidang (Islamiah et. al, 2018:47; Bungsu et. al, 2018:382; Hidayat et. al, 2018:516). Sehingga, terdapat alasan yang cukup kuat, mengapa siswa ditekankan untuk bersungguh-sungguh dalam pembelajaran matematika. Matematika akan terus dipelajari secara berkesinambungan sampai jenjang pendidikan yang paling tinggi sekalipun. Seperti yang dikemukakan oleh Ruseffendi (2006), matematika disebut dengan ratunya ilmu yang bermakna bahwa matematika tidak bergantung pada ilmu lain atau study lain. 
Permasalahannya saat ini matematika masih dipandang sebagai salahsatu mata pelajaran yang sulit bagi siswa (Bernard, Sumarna, Rolina, \& Akbar, 2019) sehingga minat siswa dalam belajar matematika rendah. Minat merupakan suatu kegiatan yang dilakukan oleh siswa secara tetap dalam melakukan proses belajar. Sesuai dengan pendapat Menurut Slameto (2003:180) minat adalah kecenderungan yang tetap untuk memperhatikan dan mengenang beberapa kegiatan. Kegiatan yang diminati siswa, diperhatikan terus-menerus yang disertai rasa senang dan diperoleh rasa kepuasan. Lebih lanjut dijelaskan minat adalah suatu rasa suka dan ketertarikan pada suatu hal atau aktivitas, tanpa ada yang menyuruh. Seseorang yang memiliki minat terhadap kegiatan tertentu cenderung memberikan perhatian yang besar terhadap kegiatan tersebut.

Maka dari itu sebagai seorang guru harus bisa menyesuaikan pembelajaran sesuai karakteristik anak (insani, et.al., 2019) dan selalu berusaha untuk menarik perhatian anak didiknya sehingga mereka mempunyai minat terhadap pelajaran yang diajarkannya. Orang yang menaruh minat pada suatu aktivitas akan memberikan perhatian yang besar. Ia tidak segan mengorbankan waktu dan tenaga demi aktivitas tersebut. Oleh karena itu seorang siswa yang mempunyai perhatian terhadap suatu pelajaran, ia pasti akan berusaha keras untuk memperoleh nilai yang bagus yaitu dengan belajar.

Tidak semua siswa menyukai suatu mata pelajaran pelajaran karena faktor minat belajarnya sendiri. Ada yang mengembangkan minat belajarnya terhadap bidang pelajaran tersebut karena pengaruh dari gurunya, teman sekelas, bahan pelajaran yang menarik. Lama-kelamaan jika siswa mampu mengembangkan minat belajarnya terhadap mata pelajaran niscaya ia bisa memperoleh prestasi yang berhasil sekalipun ia tergolong siswa yang berkemampuan rata-rata.

\section{METODE}

Metode penelitian yang digunakan adalah metode survei, dimana dalam metode penelitian ini data didapatkan dengan cara memberikan angket yang selanjutnya dianalisis secara deskriptif. Instrument yang digunakan adalah angket minat belajar terhadap pembelajaran matematika dengan 24 butir pertanyaan yang berhubungan dengan 1) perasaan (11 butir pertanyaan), 2) perhatian dalam belajar (5 butir pertanyaan), dan 3) ketertarikan pada materi dan guru (8 butir pertanyaan), dengan 2 alternatif jawaban pada angket yaitu "Ya" dan "Tidak". Populasi dari penelitian ini adalah seluruh siswa MTs Ulul Albab, sedangkan sampelnya yaitu 60 siswa dari berbagai tingkatan kelas, yang terdiri dari 30 siswa kelas VII, 30 siswa kelas VIII, dan 30 siswa kelas IX.

\section{HASIL}

Penelitian ini dibuat untuk menganalisis faktor penyebab rendahnya minat belajar siswa terhadap mata pelajaran matematika di MTs Ulul Albab. Sampel dalam penelitian ini terdiri dari 60 siswa dari berbagai tingkatan kelas di MTs Ulul Albab, yaitu 30 siswa dari kelas VII, 30 siswa dari kelas VIII, dan 30 siswa dari kelas IX. Setelah melakukan penyebaran angket minat belajar didapat data rekapitulasi minat belajar siswa yang disajikan pada tabel 1 


\section{Tabel 1.}

Rekapitulasi minat belajar siswa terhadap pembelajaran matematika

\begin{tabular}{|c|c|c|c|c|}
\hline & \multicolumn{4}{|c|}{ Penilaian } \\
\cline { 2 - 5 } & Ya & \% & Tidak & \% \\
\hline Jumlah & 598 & 9.9666667 & 842 & 14.03333 \\
\hline Rata-rata & 25 & $41.53 \%$ & 35 & $58.47 \%$ \\
\hline
\end{tabular}

Berdasarkan tabel diatas identifikasi faktor penyebab rendah minat belajar dalam mata pelajaran matematika siswa MTs Ulul Albab tahun ajaran 2018/2019 berada pada tingkat sedang $(41.53 \%)$ responden menyatakan "YA" karena siswa tidak tertarik untuk belajar matematika dan merasa kesulitan memahami pelajaran matematika yang telah dipelajari disekolah dan (58.47\%) responden yang menyatakan " TIDAK " karena siswa tertarik dengan pelajaran matematika dan merasa kesulitan untuk menerima pelajaran matematika disekolah. Data yang terkumpul dalam penelitian ini akan disajikan kedalam tabel yaitu : Penyebab rendah minat belajar dalam mata pelajaran matematika siswa MTs Ulul Albab. Yang berhubungan dengan 1) perasaan senang, 2) perhatian dalam belajar dan 3) Ketertarikan pada Materi dan Guru.

\section{Penyebab Rendahnya belajar siswa ditinjau dari perasaan senang}

Penyebab rendah minat belajar siswa ditinjau dari perasaan senang untuk melihat gambaran data pernyataan jawaban diberikan siswa MTs Ulul Albab dilihat pada tebel berikut :

\section{Tabel 2}

\section{Hasil Olah Data Penyebab Rendah Minat Belajar Matematika MTs Ulul Albab}

(Perasaan Senang, pertanyaan no. 1-11)

\begin{tabular}{|c|c|c|c|c|}
\hline \multirow{2}{*}{} & \multicolumn{4}{|c|}{ Penilaian } \\
\cline { 2 - 5 } & Ya & \% & Tidak & \% \\
\hline Jumlah & 292 & 4.866667 & 368 & 6.133333 \\
\hline Rata-rata & 27 & $44.24 \%$ & 33 & $55.76 \%$ \\
\hline
\end{tabular}

Dari tabel 2 diatas dapat diketahui bahwa dari 60 jumlah siswa yang mengalami rendah minat belajar berdasarkan indikator perasaan senang yang terlihat dari rata - rata presentase skor yaitu (44.24 $\%)$ siswa yang menyatakan ya berarti dalam tingkat sedang dan $(55.76 \%)$ siswa yang menyatakan tidak. Seorang siswa yang memiliki perasaan senang atau suka terhadap pelajaran matematika misalnya, maka ia harus terus mempelajari ilmu yang berhubungan dengan matematika. Sama sekali tidak ada perasaan terpaksa untuk mempelajari bidang tersebut.

Pada umumnya individu yang suka pada sesuatu disebabkan karena adanya minat. biasanya apa yang paling disukai mudah sekali untuk diingat. Sama halnya dengan siswa yang berminat pada suatu mata pelajaran tertentu akan menyukai pelajaran itu. Kesukaan ini tampak dari kegairahan dan inisiatifnya dalam mengikuti pelajaran tersebut. Kegairahan dan inisiatif ini dapat diwujudkan dengan berbagai usaha yang dilakukan untuk menguasai ilmu pengetahuan yang terdapat dalam mata pelajaran 
tersebut dan tidak merasa lelah dan putus asa dalam mengembangkan pengetahuan dan selalu bersemangat, serta bergembira dalam mengerjakan tugas ataupun soal yang berkaitan dengan pelajaran yang diberikan guru di sekolah.

\section{Penyebab rendahnya minat belajar siswa ditinjau dari perhatian belajar.}

Gambaran data jawaban pernyataan yang diberikan siswa tentang penyebab rendah minat belajar matematika siswa ditinjau dari perhatian belajar siswa MTs Ulul Albab secara rinci dapat dilihat dalam tabel berikut :

\section{Tabel 3}

Hasil Olah Data Penyebab Rendah Minat Belajar Matematika siswa MTs Ulul Albab (Perhatian Belajar, pertanyaan no.12-16)

\begin{tabular}{|c|c|c|c|c|}
\hline & \multicolumn{4}{|c|}{ Penilaian } \\
\cline { 2 - 5 } & Ya & \% & Tidak & \% \\
\hline Jumlah & 138 & $230.00 \%$ & 162 & $270.00 \%$ \\
\hline Rata-rata & 28 & $46.00 \%$ & 32 & $54.00 \%$ \\
\hline
\end{tabular}

Dari tabel 3 diatas dapat diketahui bahwa dari 60 jumlah siswa yang berasal dari perhatian belajar yang mengalami rendah minat belajar matematika terlihat dari rata - rata prosentase skor yaitu $46.00 \%$ yang menyatakan ya berarti dalam tingkat sedang dan 54.00\% yang menyatakan tidak. Adanya perhatian juga menjadi salah satu indikator minat belajar. Perhatian merupakan konsentrasi atau aktifitas jiwa kita terhadap pengamatan, pengertian, dan sebagainya dengan mengesampingkan yang lain dari pada itu. Seseorang yang memiliki minat belajar pada objek tertentu maka dengan sendirinya dia akan memperhatikan objek tersebut. Misalnya, seorang siswa menaruh minat belajar terhadap pelajaran Sains, maka ia berusaha untuk memperhatikan penjelasan dari gurunya

Jika dilihat penyebab rendah minat belajar pada item tidak pernah membuat keributan pada saat belajar matematika dikelas berkisar antara $50.00 \%$ yang menyatakan ya dan $50 \%$ yang menyatakan tidak, Oleh karena itu minat mempunyai pengaruh yang besar dalam belajar karena bila bahan pelajaran yang dipelajari tidak sesuai dengan minat siswa maka siswa tersebut tidak akan belajar dengan sebaikbaiknya, sebab tidak ada daya tarik baginya. Sedangkan bila bahan pelajaran itu menarik minat siswa, maka ia akan mudah dipelajari dan disimpan karena adanya minat sehingga menambah kegiatan belajar.

\section{Penyebab rendahnya minat belajar siswa ditinjau dari ketertarikan pada materi dan guru}

Gambaran data jawaban pernyataan yang diberikan siswa tentang Penyebab rendahnya minat belajar siswa ditinjau ketertarikan pada materi dan guru secara rinci dapat dilihat tabel dalam berikut :

\section{Tabel 4}

Hasil Olah Data Penyebab Rendah Minat Belajar Matematika siswa MTs Ulul Albab

(Ketertarikan Pada Materi Dan Guru, pertanyaan no. 17-24)

\begin{tabular}{|c|c|c|c|c|}
\hline & \multicolumn{4}{|c|}{ Penilaian } \\
\cline { 2 - 5 } & Ya & \% & Tidak & \% \\
\hline Jumlah & 168 & $280.00 \%$ & 312 & $520.00 \%$ \\
\hline Rata-rata & 21 & $35.00 \%$ & 39 & $65.00 \%$ \\
\hline
\end{tabular}


Berdasarkan tabel 4. dapat diketahui bahwa dari 60 orang siswa yang mengalami rendah minat belajar, yang berhubungan dengan ketertarikan pada materi dan guru yang terlihat dari rata-rata prosentase skor yaitu $35.00 \%$ siswa menyatakan iya berarti dalam tingkat rendah $65.00 \%$ siswa menyatakan tidak dalam hal ketertarikan, seringkali dijumpai beberapa siswa yang merespon dan memberikan reaksi terhadap apa yang disampaikan guru pada saat proses belajar mengajar di kelas. Tanggapan yang diberikan menunjukkan apa yang disampaikan guru tersebut menarik perhatiannya, sehingga timbul rasa ingin tahu yang besar.

Dan jika dilihat presentase nilai skor masing - masing item yang berkisar antara 30\% sampai 45\% maka penyebab rendah minat belajar matematika pada siswa ditinjau dari ketertarikan pada materi dan guru menunjukkan pada proporsi sebagian, maksudnya siswa mengalami rendah minat belajar yang berhubungan dengan ketertarikan pada materi dan guru.

Ketiadaan minat terhadap suatu mata pelajaran menjadi pangkal penyebab kenapa anak didik tidak bergeming untuk mencatat apa-apa yang telah disampaikan oleh guru. Itulah sebagai pertanda bahwa anak didik tidak mempunyai motivasi untuk belajar. Oleh karena itu guru harus bisa membangkitkan minat anak didik. Sehingga anak didik yang pada mulanya tidak ada hasrat untuk belajar, tetapi karena ada sesuatu yang dicari muncullah minatnya untuk belajar.

Bertitik tolak dari temuan hasil penelitian ini terungkap bahwa faktor penyebab rendah minat belajar pada siswa cukup bervariasi yaitu penyebab rendah minat belajar siswa berdasarkan 3 indikator yaitu : 1) perasaaan senang, 2) perhatian belajar dan 3) ketertarikan pada materi dan guru. Penyebab rendah minat belajar siswa yang bervariasi ini memerlukan pembinaan dengan masih besarnya angka persentase yang ditujukan siswa untuk jawaban "tidak", dan kecilnya angka persentase untuk pernyataan "ya". Pembahasan disesuaikan dengan setiap kelompok penyebab rendah minat belajar yang criteria penafsiran presentase tercantum pada tabel 3 .

\section{Penyebab rendah minat belajar siswa ditinjau dari perasaan senang}

Temuan penelitian menggambarkan secara keseluruhan tentang penyebab rendah minat belajar siswa ditinjau dari perasaan senang cukup bervariasi, hal ini perlu dibina dan dituntaskan permasalahan siswa tersebut. Hasil penelitian ini menunjukkan bahwa sebagian besar siswa merasa pelajaran matematika pelajaran yang sulit, hal ini menunjukkan bahwa minat merupakan kecenderungan yang relatif tetap untuk lebih memperhatikan dan mengingat secara terus menerus yang diikuti rasa bangga, senang serta memperoleh suatu kepuasan dalam mencapai tujuan pembelajaran.

Tercapainya tujuan pembelajaran ditandai dengan hasil belajar yang diperoleh meningkat. Minat merupakan sumber dorongan kemauan yang kuat untuk belajar. Siswa yang mempunyai minat tinggi dalam kegiatan belajar akan berusaha keras dalam belajar, dibandingkan dengan siswa yang kurang berminat dalam belajar. Sehingga Minat belajar siswa akan berhubungan dengan meningkatnya hasil belajar khususnya pada mata pelajaran matematika. 


\section{Penyebab rendah minat belajar siswa ditinjau dari perhatian belajar}

Temuan penelitian menggambarkan bahwa secara keseluruhan tentang penyebab rendah minat belajar siswa ditinjau dari perhatian belajar cukup bervariasi, hal ini perlu dibina, dituntaskan permasalahan siswa tersebut. Hasil penelitian menunjukkan sebagian besar siswa mengalami rendah minat dalam memahami materi pelajaran yang ia pelajari meskipun sudah berusaha untuk memahaminya, dan semua jawaban siswa tentang pernyataan item soal pada perhatian belajar ini menunjukkan sebagian besar perhatian belajar sangat dipengaruhi oleh perasaan dan suasana hati seseorang yang ditentukan oleh kemauan.

Temuan penelitian menggambarkan bahwa secara keseluruhan tentang penyebab rendah minat belajar siswa ditinjau dari ketertarikan pada materi dan guru cukup bervariasi. Hal ini perlu diperbaiki dan dituntaskan permasalahan siswa tersebut.

Hasil penelitian sebagian besar siswa tertarik kepada guru, artinya tidak membenci atau bersikap acuh tak acuh, tertarik kepada mata pelajaran yang diajarkan, mempunyai antusias yang tinggi serta mengendalikan perhatiannya terutama kepada guru, ingin selalu bergabung dalam kelompok kelas, ingin identitas dirinya diketahui oleh orang lain, tindakan kebiasaan dan moralnya selalu dalam kontrol diri, selalu mengingat pelajaran dan mempelajarinya kembali, dan selalu terkontrol oleh lingkungannya

\section{KESIMPULAN}

Berdasarkan hasil penelitian dapat ditarik kesimpulan tentang faktor penyebab rendahnya minat belajar siswa pada mata pelajaran matematika dipengaruhi (41.53\%) pada tingkatan sedang cukup menentukan rendahnya minat belajar matematika, keadaan ini diharapkan adanya peningkatan lagi untuk pada masa yang akan datang, untuk setiap indikatornya dapat disimpulkan bahwa :

1. Faktor perasaan senang yang dapat menyebabkan rendahnya minat belajar siswa dalam mata pelajaran matematika di MTs Ulul Albab termasuk dalam tingkatan sedang yang ditunjukkan oleh hasil pengolahan data sebesar (44.24\%). Hal ini membuktikan bahwa penyebab rendah minat belajar seorang siswa yang tidak memiliki perasaan senang atau tidak suka terhadap pelajaran matematika misalnya, maka ia tidak akan mempelajari ilmu yang berhubungan dengan matematika. Dan ada perasaan terpaksa untuk mempelajari bidang tersebut.

2. Faktor perhatian dalam belajar yang dapat menyebabkan rendahnya minat belajar siswa dalam mata pelajaran matematika di MTs Ulul Albab termasuk dalam tingkatan sedang yang ditunjukkan oleh hasil pengolahan data sebesar (46.00\%). Hal ini membuktikan bahwa penyebab rendah minat belajar pada perhatian belajar merupakan konsentrasi atau aktifitas jiwa terhadap pengamatan dan pengertian, dengan mengesampingkan yang lain dari pada itu. Siswa yang tidak memiliki minat pada objek tertentu, maka dengan sendirinya tidak akan memperhatikan objek tersebut.

3. Faktor ketertarikan pada materi dan guru yang dapat menyebabkan rendahnya minat belajar siswa dalam mata pelajara nmatematika di MTs Ulul Albab termasuk dalam tingkatan rendah yang ditunjukkan oleh hasil pengolahan data sebesar (35.00\%). Hal ini membuktikan bahwa penyebab 
rendah minat belajar berhubungan dengan daya gerak yang mendorong siswa untuk cenderung merasa tertarik pada orang, benda, kegiatan, atau bisa berupa pengalaman efektif yang dirangsang oleh kegiatan itu sendiri.

Berdasarkan hasil penelitian yang telah dilakukan, terdapat beberapa saran yang diantaranya:

1. Guru sebagai pendidik harus memperhatikan masing-masing siswa dan mengidentifikasi apa yang menjadi penyebab rendahnya minat belajar siswa khususnya mata pelajaran matematika.

2. Guru dalam tugasnya sebagai pendidik harusnya kreatif dan mempunyai inovasi-inovasi dalam pengembanganmetode pelajaran, sehingga minat siswa dalam mengikuti pembelajaran tinggi.

3. Guru harus mempunyai tindak lanjut yang tepat untuk mengatasi masalah penyebab rendahnya minat belajar siswa khususnya mata pelajaran matematika.

\section{DAFTAR PUSTAKA}

Akbar, P., Hamid, A., Bernard, M., \& Sugandi, A. I. (2018). Analisis Kemampuan Pemecahan Masalah dan Disposisi Matematik Siswa Kelas XI SMA Putra Juang dalam Materi Peluang. Jurnal Cendekia: Jurnal Pendidikan Matematika, 2(1), 144-153.

Bungsu, T. K., Vilardi, M., Akbar, P., \& Bernard, M. (2018). Pengaruh Kemandirian Belajar Terhadap Hasil Belajar Matematika Di Smkn 1 Cihampelas. Journal on Education, 1(2), 382-389.

Bernard, M., Akbar, P., Ansori, A., \& Filiestianto, G. (2019, October). Improve the ability of understanding mathematics and confidence of elementary school students with a contextual approach using VBA learning media for Microsoft Excel. In Journal of Physics: Conference Series (Vol. 1318, No. 1, p. 012035). IOP Publishing.

Bernard, M., Sumarna, A., Rolina, R., \& Akbar, P. (2019, October). Development of high school student work sheets using VBA for microsoft word trigonometry materials. In Journal of Physics: Conference Series (Vol. 1315, No. 1, p. 012031). IOP Publishing.

Chotimah, S., Ramdhani, F. A., Bernard, M., \& Akbar, P. (2018). Pengaruh Pendekatan Model-Eliciting Activities Terhadap Kemampuan Berpikir Kritis Matematik Siswa Smp Negeri Di Kota Cimahi. Journal on Education, 1(2), 68-77.

Hidayat, F., Akbar, P., \& Bernard, M. (2018). Analisis Kemampuan Berfikir Kritis Matematik Serta Kemandiriaan Belajar Siswa Smp Terhadap Materi Spldv. Journal on Education, 1(2), 515-523.

Insani, S. U., \& Akbar, P. (2019, October). Development of Open-Ended Based Mathematics Problem to Measure High-Level Thinking Ability. In Journal of Physics: Conference Series (Vol. 1315, No. 1, p. 012047). IOP Publishing.

Islamiah, N., Purwaningsih, W. E., Akbar, P., \& Bernard, M. (2018). Analisis Hubungan Kemampuan Pemecahan Masalah Matematis dan Self Confidence Siswa SMP. Journal on Education, 1(1), 47-57.

Isnaeni, S., Ansori, A., Akbar, P., \& Bernard, M. (2018). MATERI PERSAMAAN DAN PERTIDAKSAMAAN LINEAR SATU. 01(02), 309-316 
Rahmawati, N. S., Bernard, M., \& Akbar, P. (2018). ANALISIS KEMAMPUAN KOMUNIKASI MATEMATIK SISWA SMK PADA MATERI SISTEM PERSAMAAN LINIER DUA VARIABEL (SPLDV). Journal on Education, 1(2), 344-352.

Rasnawati, A., Rahmawati, W., Akbar, P., \& Putra, H. D. (2019). Analisis Kemampuan Berfikir Kreatif Matematis Siswa SMK Pada Materi Sistem Persamaan Linier Dua Variabel (SPLDV) Di Kota Cimahi. Jurnal Cendekia: Jurnal Pendidikan Matematika, 3(1), 164-177.

Ruseffendi, E.T. (2006). Pengantar kepada Membantu Guru Mengembangkan Kompetensinya dalam pengajaran Matematika untuk meningkatkan CBSA. Bandung: Tarsito.

Slameto (2003) Belajar dan Faktor-faktor yang Mempengaruhinya. Jakarta : Rineka Cipta

Sugandi, A. I., \& Akbar, P. (2019). Efektivitas Penerapan Strategi React Terhadap Kemampuan Koneksi Matematis dan Self-Efficacy Siswa SMP. Jurnal Cendekia: Jurnal Pendidikan Matematika, 3(2), 431-436.

Wiliawanto, W., Bernard, M., Akbar, P., \& Sugandi, A. I. (2019). Penerapan Strategi Pembelajaran Aktif Question Student Have Untuk Meningkatkan Kemampuan Berpikir Kritis Matematik Siswa SMK. Jurnal Cendekia: Jurnal Pendidikan Matematika, 3(1), 139-148. 